\section{Notaike}

Vol. 2 No. 1, Februari 2019
e-ISSN: 2655-9404

DOI: $10.20473 /$ ntr.v2i1.13055

Article history: Submitted 15 December 2018 ; Accepted 8 January 2019; Available online 1 February 2019.

\title{
Aesthetic Performance Products as a Basis For Non Novelty of Industrial Design Based on the Public Domain Principle
}

\author{
Puteri Melati, Desy Rizki Ramadhani and Camellia Anand \\ puteri9494@gmail.com \\ Universitas Airlangga
}

\begin{abstract}
Comparative products are very important and must be considered about it because, Industrial Design assesses the performance of products that can be proven from evidence that can be seen or assessed by clear eye such as photographic evidence, catalogs or other evidence that can be proved bye Industrial Design which has existed before. Industrial design is based on its external appearance which does not have an aesthetic impression and contradicts Article 1 point 1 of the Industrial Design Law and article 25 Paragraph 1 of the TRIPs agreement, which is form creation, solely for function or technical configuration. Aesthetically cannot be registered. In the absence of aesthetic elements, the product performance can be used as the basis for the absence of new industrial designs based on the principle of "Public Domain", considering the aesthetic elements are one of the requirements of an item that can be categorized as Industrial Design. In the other hand, the protection period has expired and became a "Public Domain" then it can be registered as an Industrial Design if it packed with an aesthetic elements. If an item does not have an aesthetic impression, it can be ascertained that the item is not an industrial design and can be possible not to have novelty and become public property. Aesthetic impressions do not contradict with the laws and regulations, but this is an important requirement so the design can be categorized as an industrial design. In ordinance No. 31 in 2000 concerning Industrial Design itself does not limit of the notion novelty and aesthetics so, the multiple interpretations are often occur.
\end{abstract}

Keywords: Aesthetic Performance Product; Novelty Industrial Design; Public Domain Principle.

\begin{abstract}
Abstrak
Produk pembanding sangatlah penting atau menjadi hal utama yang harus diperhatikan karena Desain Industri menilai performa produk yang hanya dapat dibuktikan dari bukti yang dapat dilihat atau dinilai oleh kasat mata seperti bukti foto, katalog atau bukti lainnya yang dapat membuktikan bahwa Desain Industri tersebut telah ada sebelumnya. Desain Industri berdasarkan tampilan luarnya yang tidak memiliki kesan estetis dan bertentangan dengan Pasal 1 angka 1 Undang-Undang Desain Industri dan pasal 25 ayat 1 perjanjian TRIPs yaitu Kreasi bentuk, konfigurasinya sematamata untuk fungsi atau teknis yang biasa perlindungannya pada Paten bukan bertujuan memberikan kesan estetis tidak dapat didaftarkan. Maka dalam hal ketiadaan unsur estetika, performa produk dapat dijadikan sebagai dasar tidak adanya kebaruan desain industri berdasarkan prinsip "public domain", mengingat unsur estetika merupakan salah satu syarat suatu barang dapat dikategorikan sebagai Desain Industri. Sehingga ketika masa perlindungan paten tersebut telah habis dapat dan menjadi "public domain" maka dapat didaftarkan lagi sebagai Desain Industri bila dikemas dengan unsur estetik. Apabila suatu barang tersebut tidak memiliki kesan estetika di dalamnya maka dapat dipastikan barang tersebut bukan merupakan desain industri dan dapat dimungkinkan tidak memiliki kebaruan dan menjadi milik umum. Kesan estetis memang tidak bertentangan dengan peraturan perundang-undangan, namun kembali lagi hal tersebut merupakan syarat penting agar suatu desain dapat dikategorikan sebagai desain industri. Undang Nomor 31 Tahun 2000 tentang Desain Industri sendiri tidak membatasi pengertian kebaruan dan estetis sehingga sering terjadi multi tafsir. Kata Kunci: Estetika Performa Produk; Kebaruan Desain Industri; Prinsip Publik.
\end{abstract}




\section{Introduction}

Humans are required to think in order to develop the economic sector to keep up with the flow of globalization. Indonesia as a developing country needs to advance the industrial sector in order to advance national development. Economic development is closely related to science and technological progress. Intellectual Property Rights are tangible evidence of the realization of human thought in the form of creation or invention. In the strict sense of IPR was addressed to "copyright", while in the broadest sense the intellectual property rights in it include rights to industrial wealth and considered in a single term, named intellectual property rights (IPR). ${ }^{1}$

The right of Industrial Design is part of Industrial Property and this property right is a branch of Intellectual Property Rights (IPR). The Right of Industrial Design had a Law that has been established by the Indonesian government, in ordinance Number 31 in 2000 concerning Industrial Design of the State Gazette Number 243 in 2000, hereinafter referred to as the Industrial Design Law. The Industrial Design Law is an instrument that cannot be separated from encouraging comprehensive legal protection. ${ }^{2}$ The Right of Industrial Design needs a protection. This is intended to protect the creativity of the designer. Furthermore, the designer will continued to make new designs.

Industrial design has a definition according to Article 1 point 1 of Law No.31 in 2000 concerning Industrial Design:

"Industrial design is a creation of the shape, configuration, or composition of lines or colors, lines and colors, or a combination of three-dimensional or two-dimensional shapes that give an aesthetic impression and can be realized in three-dimensional or two-dimensional patterns and can be used to produce a product, item, industrial commodity, or handicraft."

In the definition of Industrial Design Article 1 point 1 of Law No.31 in 2000, it can be concluded that one of the requirements included in the industrial design category is that the creation of the form must be give an aesthetic impression. The

\footnotetext{
${ }^{1}$ Sophar Maru Hutagalung, Hak Cipta Kedudukan Dan Peranannya Dalam Pembangunan (Sinar Grafika 2012).[123].

${ }^{2}$ Budi Agus Riswandi dan M. Syamsudin, Hak Kekayaan Intelektual Dan Budaya Hukum (PT RajaGrafindo Persada 2004).[52].
} 
aesthetic definition comes from the word aesthetic which mean beauty; concerning appreciation of beauty (nature, art, and literature) or having an assessment of beauty. Then, the aesthetic impression is not concerned with right or wrong, but it is beautiful or not. Whether or not, the aesthetic impression given by a creation can be known if the creation seen by the clear eye. There is a problem whether the proof of the performance of comparative products is the basic things which can be prove by the product.

The definition of Industrial Design according to Article 1 point 1 of Law No.31 in 2000 concerning Industrial Design can be concluded that one of the requirements included in the industrial design category is that the creation of the form must give an aesthetic impression. According to Article 2 of Law No. 31 in 2000 concerning Industrial Design, the Right of Industrial Design can be granted if The Right of Industrial Design is granted for the new Industrial Design.

Industrial Design is considered new if on the Receipt Date, the Industrial Design is not the same as the pre-existing disclosure. Previous disclosures, as referred to in paragraph (2) are disclosures of Industrial Designs which before receipt date; or priority date if the Application is submitted with Priority Rights; has been announced or used in Indonesia or outside Indonesia.

Furthermore, in Article 4 of Law No. 31 in 2000 concerning Industrial Design, Industrial Designs that do not receive protection are: "The right of industrial design cannot be granted if the industrial design is contrary to the applicable laws and regulations, public order, religion or morality".

Based on the statement, the problem arises that the element of aesthetic impressions that play an important role in industrial design. Turns out that in those articles both Article 2 regulates the conditions for granting Industrial Design Rights and Article 4 which regulates matters whatever causes the Industrial Design Right to be granted and also Article 10, 11, 12, 13, 14 The Industrial Design Law concerning the application for industrial design registration does not include the aesthetic impression therein, so that the use of the aesthetic impression itself can be questioned. If the absence of aesthetic elements cannot be the basis that the 
Industrial Design is not an Industrial Design. In the aesthetic element as the basis that the Industrial Design is not new based on the principle of "Public Domain".

Industrial Design Rights are given for new industrial designs. This means that only industrial design has a novelty element that can be given legal protection and by itself can be registered, where Industrial Design is considered new if on the date of receipt of the registration application by the Directorate General of Intellectual Property Rights, industrial design is not the same as disclosure beforehand, whereas what is meant by previous disclosures is industrial design disclosure before the date of receipt of an application or priority date in the event the application is submitted with priority rights, or has been announced or used in Indonesia or outside Indonesia.

A parameter requires a proof that the value in a similar product can be a differentiating value for the product that has been made before and has a difference for ordinary people. Although, the industry's submission to the value of a product occasionally raises the same results, it is a legal mistake to test based on these two parameters. For example there are claims or demands on the whole product that are not based on new things.

The comparison of the product in the industry includes two separate parameters, which are based on the observations of ordinary people and the parameters. They must be fulfilled to find whether there is a violation in the industry.

In the eyes of ordinary people, the buyer sometimes confused with two products that have similarities with each other. For example, the first product is already available, while the second product is not. Because of the price of the second product is cheaper, and the similarity, the buyer choose the second product. In other words, there is no industrial violation if the whole product is not same. But in this case, it is emphasized that the analysis of a layman is based on his own observations and does not based on the opinions of experts.Based on parameters, the finder must determine whether a product is in accordance with the point that can be a differentiator to the previous product. Furthermore, publications that were previously evaluated to determine product whether the developed of an invention can be easily recognized. Furthermore, an invention is compared to the pre-existing 
one to another determine, whether the new invention has more advantage than before. That way of a test always compares old products with new one to evaluate a relative advantage. So the value is related to the difference in the previous product, and it generally based on the history of the prosecution.

If there are only a few different elements, based on the shape, configuration, or composition of the color, it can be said to be new. In other words, even though it is similar, it is still considered the difference. In the description, the new criteria in the Industrial Design Law allow many conflicts or disputes in the field because products which are in the market have similarities, but industrial design certificate holders are difficult to be able to sue other parties who are considered to be violating, the design of the other party must be really the same.

\section{The Aesthetic Performance Product}

Industrial design has a definition according to Article 1 point 1 of Law No.31 of 2000 concerning Industrial Design, that is:

"Industrial design is a creation of the shape, configuration, or composition of lines or colors, or lines and colors, or a combination of three-dimensional or two-dimensional shapes that give an aesthetic impression and can be realized in three-dimensional or two-dimensional patterns and can be used to produce a product, item, industrial commodity, or handicraft."

From the definition of Industrial Design above, we can draw a conclusion that one of the requirements included in the industrial design category is that the form creation must give an aesthetic impression. The aesthetic definition itself comes from the word aesthetic which means beauty; concerning appreciation of beauty (nature, art, and literature) or having a valuation of beauty. So the aesthetic impression does not concerning with right or wrong, but more to beautiful or not beautiful. Whether or not the aesthetic impression given by a creation can only be known if the creation can be seen by the eye.

The three elements of art, technology and science combine harmoniously to form a design that is expected to provide technical functions and beauty that can meet human needs. The technical functions aspects arise from the technology and 
science elements, while the beauty aspect comes from the elements of art applied to a product. ${ }^{3}$
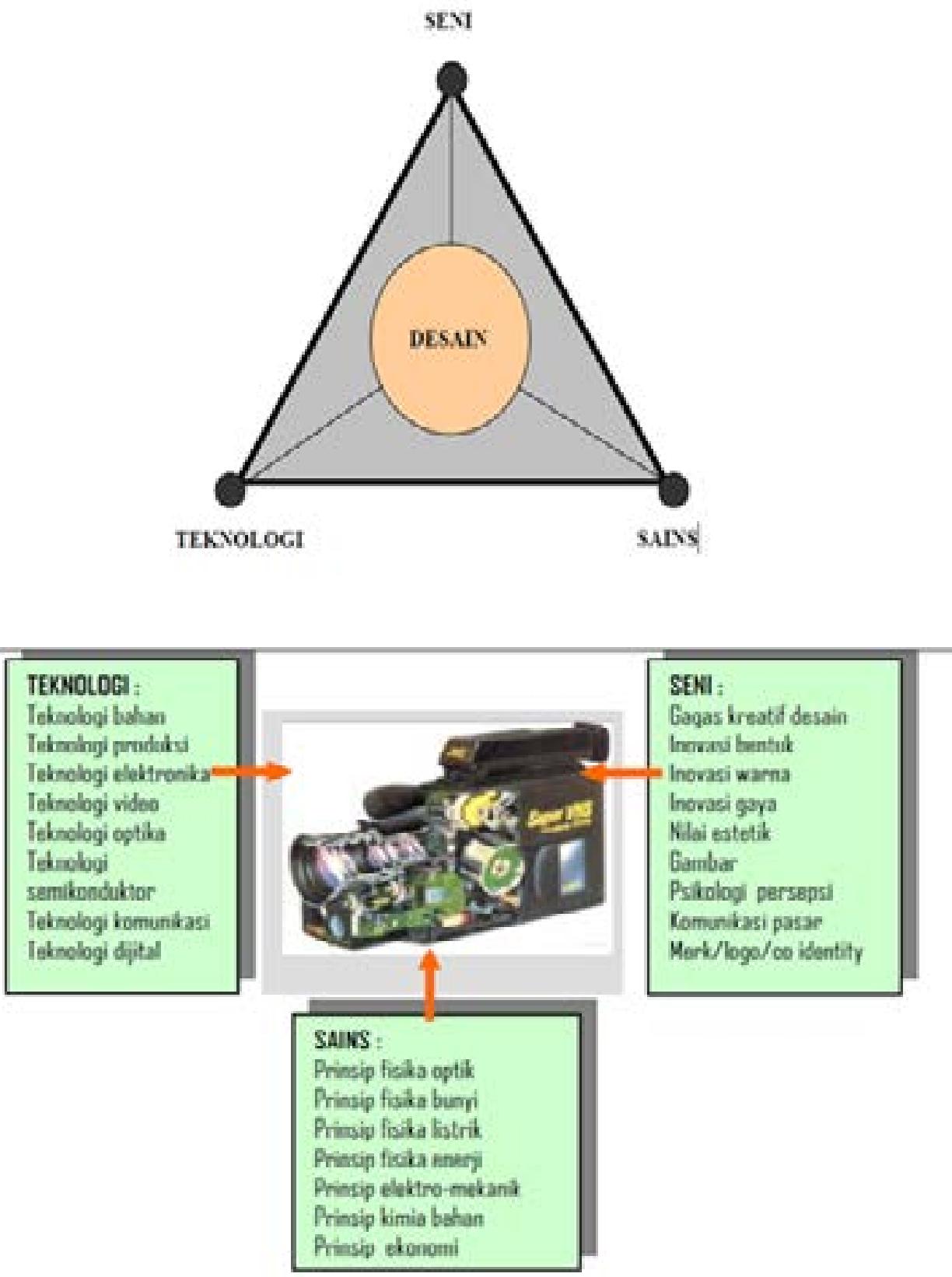

Aesthetics or beauty is a condition that related to the beauty sensation that felt by a person, but the sense of that beauty will be felt when a harmonious blend

${ }^{3}$ Direktorat Jenderal Hak Kekayaan Intelektual Kementerian Hukum \& Hak Asasi Manusia R.I. Jakarta. 2012. Pelatihan Konsultan Hak Kekayaan Intelektual, Modul: Desain Industri, PrinsipPrinsip Dasar Desain Industri. P. 3 
of elements of beauty is contained in an object. ${ }^{4}$ The beauty factor has extrinsic and intrinsic values, where extrinsic value is closely related to the outer form (impression), while intrinsic value is closely related to the message or meaning contained in it. ${ }^{5}$

The aesthetical design development was essentially based on elements that can support the aesthetic aspects of a work, without neglecting aspects of function, construction, technic and structure, but preferably on aspects that are visually capable on giving an aesthetic impression (extrinsic) and an aesthetic message ( intrinsic). ${ }^{6}$ So the success of work design is determined by visual perception which is aesthetic factors, besides the other factors such as: structural factors, physical condition, construction, material, economic, social, cultural, behavioral patterns and ergonomics. In the implementation process, esthetics succeeded in giving added value which psychologically would create a beautiful image, a sense of satisfaction and pride for the consumer. ${ }^{7}$

As the author stated earlier in Article 1 Number 1 of Law Number 31 of 2000 concerning Industrial Design, Industrial Design whose design is merely functional or technical (engineering design) also cannot be granted the right of Industrial Design, because this is not in compatible with the definition of Industrial Design which is basically the applied creation aims to give an aesthetic impression. ${ }^{8}$ Even this has been mandated in Article 25 Paragraph (1) of TRIPs Agreement, that is:

"Member shall provide for the protection of independently created industrial designs that are new or original. Members may provide that designs are not new or original if they do not significantly differ from known design or combinations of known design features. Members may provide that such protection shall not extend to designs dictated essentially by technical or functional consideration."

Based on the article, it was agreed that WTO member countries should

\footnotetext{
${ }^{4}$ Artini Kusmiati, Dimensi Estetika Pada Karya Arsitektur Dan Desain (Djambatan 2004).[5].

5 ibid [1].

${ }^{6}$ ibid. [7].

7 ibid. [9].

${ }^{8}$ Direktorat Jenderal Hak Kekayaan Intelektual Kementerian Hukum \& Hak Asasi Manusia
} R.I. Jakarta. Op.cit. [33]. 
provide a protection against industrial design which independent and creative with the requirement that the industrial design rights granted must be novelty or original.

\section{The Novelty of Industrial Design Based on Public Domain Principle}

According to Article 2 of Law No. 31 of 2000 concerning Industrial Design, the Industrial Design Right can be granted if:

1. The Industrial Design Right is granted for the new Industrial Design.

2. Industrial Design is considered new if on the Receipt Date, the Industrial Design is not the same as the pre-existing disclosure.

3. Previous disclosures, as referred to in paragraph (2) are disclosures of Industrial Designs which before:

a. receipt date; or

b. priority date if the Application was submitted with Priority Rights; has been announced or used in Indonesia or outside Indonesia.

Furthermore, in Article 4 of Law No. 31 of 2000 concerning Industrial Design, Industrial Designs that does not receive some protection are: "The right of industrial design cannot be granted if the industrial design is contrary to the applicable laws and regulations, public order, religion or morality."

Based on the statement above, the problem arises that the aesthetic impressions that play an important role in industrial design in fact in those articles governing the definition and granting of industrial design rights also does not include the aesthetic impression in them, so that the use of aesthetic impressions can be questioned itself.

In the Industrial Design Act there is no explanation about the aesthetic impressions. As stated in Article 1 point (1) of Law No. 31 of 2000 concerning Industrial Design explains the definition of what industrial design is. Industrial Design is:

"A creation of the shape, configuration, or composition of lines or colors, or lines and colors, or a combination of three-dimensional or two-dimensional shapes that give an aesthetic impression and can be realized in threedimensional or two-dimensional patterns and can be used to produce a product, goods, industrial commodities, or handicrafts." 
In this case the aesthetic impression has become ambiguous and may later become a problem due to the absence of an explanation of the aesthetic impression itself. Like an Electric Heaters that are disputes where the absence of aesthetic impressions should be the basis of refusing the registration of Industrial Design Right. This happened because there is no explanation regarding the aesthetic requirements in the registering process of industrial design in its administrative and in its substantive examination. The problem is when the Electric Heater which does not have an aesthetic impression has gone through an administrative examination which later given an exclusive rights. So, the Electric Heater has received a protection and legal force. According to Article 4 of the Industrial Design Law, industrial designs that can be given protection are designs that do not conflict with laws and regulations, public order, religion or morality. Aesthetic impressions indeed does not conflict with the laws and regulations, but again, this is an important requirement so that a design can be categorized as an industrial design. How can an industrial design be given the protection of industrial design rights if the design cannot be categorized as an industrial design if one of the main requirements is an aesthetic impression with no explanation at all and can lead to different interpretations, because aesthetics are a subjective requirement for each individuals that can diverse in understanding because there are no clear boundaries.

Industrial designs that cannot be registered are those that does not meet the substance requirements, one of them is Industrial Design Creation that does not aim to give an aesthetic impression (not in compatible with Ps.1 (1) Law No. 31/2000)9:

1. Creation of forms, configuration solely for functions or technicalities whose the usual protection is in patents and is not aimed to giving an aesthetic impression cannot be registered, ex : gear, piston, carburetor, etc. (Provisions of Article 25 (1) TRIPs)

\footnotetext{
9 Power Point Tim Pengajar Pelatihan Konsultan HKI Direktorat Jenderal Hak Kekayaan Intelektual Departemen Hukum \& Hak Asasi Manusia R.I. Jakarta. 2012. MODUL: DESAIN INDUSTRI Pendaftaran Desain Industri.
} 
2. Systems, processes, methods for certain technical functions cannot be registered, ex : Computer programs, production processes, etc.

Picture 1 and 2. Gear and Pocket Camera Technology are not Industrial Designs
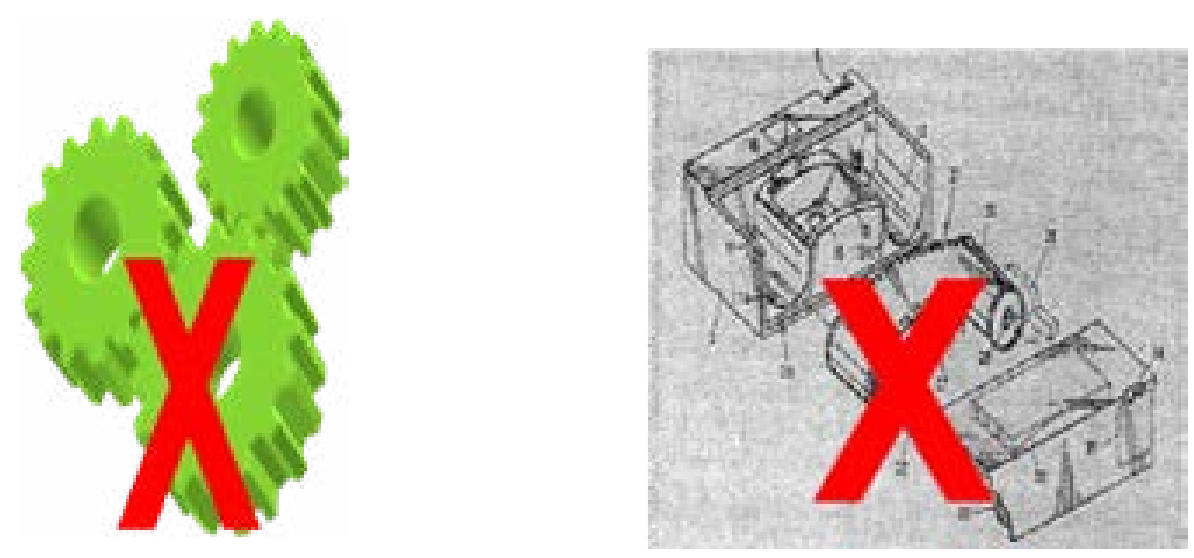

In carrying out an assessment of the industrial design novelty, there is a procedure that must be performed by the examiner, that is: $:^{10}$

a. Looking for contents in connection with the proposed industrial design. In this stage the examiner looks for:

1) Basic shape

2) Detail form of each part, and

3) Identity of a product.

b. Look for the contents of industrial design based on an objection.

c. Look for common points and different points from several industrial designs.

d. Evaluation of general matters and differences from two industrial designs.

e. Conclusion of decisions on the similarity of industrial design in comprehensively.

Industrial design is said to be not new if it has been disclosed before when it was submitted for registration, in this case there are 3 possible causes for an Industrial Design that is not new: ${ }^{11}$

1. It is publicly known design, which means that the public has known it before the

${ }^{10}$ Direktorat Jendral HKI. Petunjuk Teknis Pemeriksaan Desain Industri. 2003 P. C4-C8

${ }_{11}$ Andrieansjah Soeparman, Jenis Permohonan, Penilaian Kebaruan, dan Penggunaan Hak Desain Industri di Indonesia, (Media HKI Vol . IV/ No. 5/ Oktober 2007).[14]. 
date of receipt of the application.

2. Registration has been submitted in advance by another party (first to file principle)

3. The period of industrial design protection has expired (public domain design).

If it is not new because of publicly known design or public domain design, then everyone can use and develop the Industrial Design without having to ask permission from any party. However, if it is not new because of the registration by another party beforehand, then in order to be able to use the Industrial Design, it must be authorized by the party who registered earlier.

If the precautionary principle is held firmly by the design examiner in the Industrial Design Directorate, it should be referred to as "initial refusal" or commonly referred to as office action in various IPR literature and carried out before the industrial design application is published or at the time the publication is made. The refusal was conveyed by the Directorate General of IPR at that stage and provided an opportunity for the applicant or his attorney to provide protest, objections, rebuttal, or other arguments that could be delivered in writing or by holding hearings, or verbal explanations, or face to face before the Examiners of The IPR Directorate General to provide confidence for industrial design inspectors to reject or provide registration of the proposed industrial design. So according to the author in terms of the absence of aesthetic performance, a product can be used as the basis for the absence of new industrial design based on the principle of "public domain", considering that aesthetic elements are one of the requirements of an item that can be categorized as Industrial Design. If an item does not have an aesthetic impression in it, it can be ascertained that the item is not an industrial design and may not have novelty and become public property.

\section{Conclusion}

Industrial Design Protection was gave for new designs, which means that it is not the same as the previous disclosures (vide Article 2 paragraph (1) and (2) Law No. 31 in 2000 concerning Industrial Design). Based on this provision to declare an Industrial Design as a new design there should be a detailed comparison between the 
designs that are requested with existing product designs. In the absence of aesthetic product, it can be used as a basis for the absence of new industrial designs based on the principle of "Public Domain", considering the aesthetic elements are one of the requirements of an item, so it can be categorized as Industrial Design. If an item does not have an aesthetic impression in it, it can be ascertained that the item is not an industrial design and may not have novelty and become public property.

The government should revise Law Number 31 of 2000 concerning Industrial Design which interprets the notion of aesthetic impressions in Article 1 Number 1 to avoid confusion about the notion of aesthetic impression itself and to revise Article 2 regarding the elements "not equal" and "novelty" to be clearer. In the other hand, the parties to the dispute know in more detail the regulations governing the Industrial Design. Equalization of perceptions or interpretations of novelty criteria based on interpretation by expert, DG IPR, as well as by law enforcement officers so that no more multiple interpretations arise regarding the new criteria contained in Law No. 31 in 2000 and Government Regulation Number 1 of 2005 concerning Implementation of Law Number 31 in 2000 concerning Industrial Design which can cause problems for the community.

\section{Bibliography}

Budi Agus Riswandi dan M. Syamsudin, Hak Kekayaan Intelektual Dan Budaya Hukum (PT RajaGrafindo Persada 2004).

Kusmiati A, Dimensi Estetika Pada Karya Arsitektur Dan Desain (Djambatan 2004).

Sophar Maru Hutagalung, Hak Cipta Kedudukan Dan Peranannya Dalam Pembangunan (Sinar Grafika 2012).

\section{Regulations}

Law Number 31 year 2000 concerning Industrial Design (Indonesian State Gazette Year 2000 Number 243, Additional of Indonesian State Gazette Number 4045). 


\section{Internets}

Christopher Heer, Daryna Kutsyna, 'The Basic and Benefit of Industrial Design', (2018), , <https://www.heerlaw.com/industrial-design-basics-benefits>.

'Intellectual Property Right About Industrial Design' < https://www.esa.int/About Us/Law_at_ESA/Intellectual_Property_Rights/About_industrial_designs>.

'Industrial Design Right Law and Legal Definition'< <ttps://definitions.uslegal. com/i/industrial-design-rights/ $>$.

'What Are Industrial Design Rights and Design Patents?' $<$ https://www.rocketlawyer.com/article/what-are-industrial-design-rightsand-design-patents-ps.rl>.

HOW TO CITE: Puteri Melati, Desy Rizki Ramadhani and Camellia Anand, 'Aesthetic Performance Products as a Basis For Non Novelty of Industrial Design Based on the Public Domain Principle' (2019) Vol. 2 No. 1 Notaire. 
--halaman ini sengaja dibiarkan kosong-- 